\title{
Usman Awang's Resistance to the Malay Humanity Facts in Uda and Dara Theatre Script
}

Salman Alfarisi, Muhammad Fazli Taib Saearani, Nuriadi

To Link this Article: http://dx.doi.org/10.6007/IJARBSS/v11-i12/11671

DOI:10.6007/IJARBSS/v11-i12/11671

Received: 07 October 2021, Revised: 13 November 2021, Accepted: 30 November 2021

Published Online: 11 December 2021

In-Text Citation: (Alfarisi et al., 2021)

To Cite this Article: Alfarisi, S., Saearani, M. F. T., \& Nuriadi. (2021). Usman Awang's Resistance to the Malay Humanity Facts in Uda and Dara Theatre Script. International Journal of Academic Research in Business and Social Sciences, 11(12), 1097-1115.

\section{Copyright: @ 2021 The Author(s)}

Published by Human Resource Management Academic Research Society (www.hrmars.com)

This article is published under the Creative Commons Attribution (CC BY 4.0) license. Anyone may reproduce, distribute, translate and create derivative works of this article (for both commercial and non0-commercial purposes), subject to full attribution to the original publication and authors. The full terms of this license may be seen at: http://creativecommons.org/licences/by/4.0/legalcode

Vol. 11, No. 12, 2021, Pg. 1097 - 1115

Full Terms \& Conditions of access and use can be found at http://hrmars.com/index.php/pages/detail/publication-ethics 


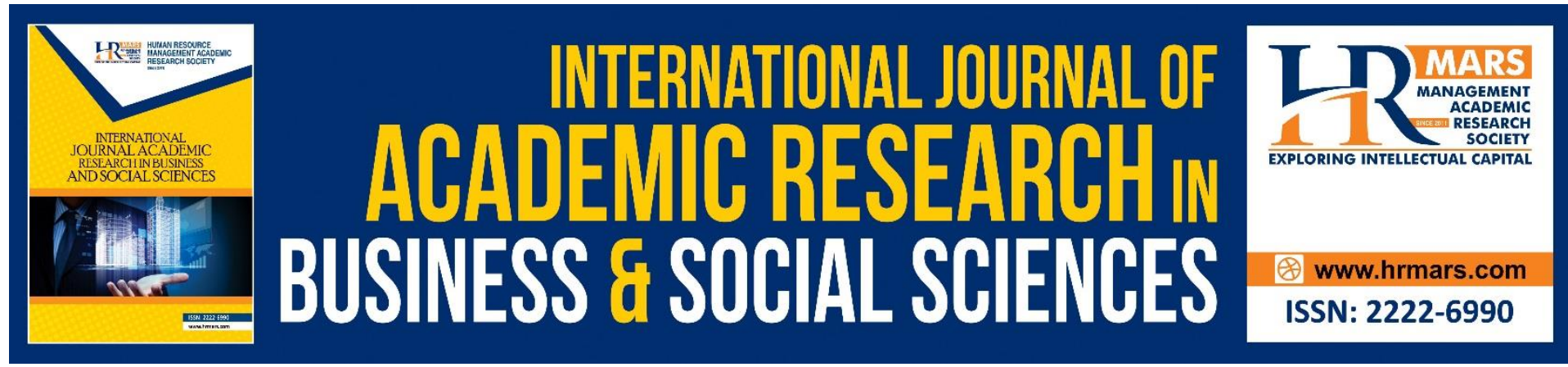

\title{
Usman Awang's Resistance to the Malay Humanity Facts in Uda and Dara Theatre Script
}

\author{
Salman Alfarisi, Muhammad Fazli Taib Saearani \\ Department of Performing Arts, Faculty of Music and Performing Arts, Sultan Idris \\ Education University, Malaysia \\ Nuriadi \\ English Education Program, Faculty of Teacher Training and Education University of \\ Mataram, Indonesia
}

\begin{abstract}
The Uda and Dara theatre script is based on the outcome of Usman Awang's observation on Malay society life, especially in the newly independent era. Since the beginning, they have taken the process to improve social development. The choices of language and determination of the characters used by Usman Awang reflect any ideas and strong critical thinking on Malay society, humanity facts that were colonized and defeated either by the real colonizers or the Malay elite themselves. Thus, it is believed that through Uda and Dara, Usman Awang fought for a social statement that was contrary to the noble values that were believed in, namely the Malays who developed social, cultural, economic, and political origins based on Islamic values. In accordance with the issue, this article focuses on the two problems. How Usman Awang's resistance to the Malay's social reality and how the Malay elite practised colonialization of fellow Malay's. The literary sociology approach and reading literary method was used to analyse Uda and Dara theatre scripts. This article shows that Usman Awang strongly criticizes the stratification or social status that only benefits the Malay elite. Through an unjust system of land tenure, the Malay elite maintained strong dominance over weaker societies. The main principal is Usman Awang was able to reveal the critical Malay's awareness to escape from the elites power who colonized them after independence from Western colonialists.
\end{abstract}

Keywords: Resistance, Humanity Facts, Malay Society

\section{Introduction}

In fact, there is much debate about literature as a human creative work. Some opinions state that literary works cannot be equated with the reality of society's life (Suharianto, 1982) and are still evolving to this day. On the other hand, language as the author's main medium of expression gives rise to a meaning that is based on the awareness of language thinking as one of the visualization spaces of social problems (Ratna, 2007). In this context, language and social problems are compounds because when language is seen as the expression of the author, it has the potentially of being born entirely from the imagination of the author, regardless of the reality of society. However, if we refer to the source of the imagination 
creator, then language can be seen as one of the estuaries where various social problems are anchored in society. This shows that reality and imagination can be in union that gives arise to the interweaving of stories in literary. In other words, this side has shown that literature can serve as a reflection on the state of society following the era spirit (Damono, 1979). Teeuw (1988) stated that the culture of a society is reflected in literature. Therefore, understanding the culture of the community is an appropriate step to explore the content of literature itself. In addition, Ratna (2003) uses the approach of literary sociology as a link between characters in literature with the experiences of real figures in the history of society. Thus, literature and society have a deep relationship because it has been written by authors who are within the time frame of being a part of society themselves. As part of a society, the author absorbs all the realities around that times that are within his reach before expressing them into literary works. After that, literature is created by the public to look back at their part of themselves. Thus, it is not an exaggeration if Damono (1979) states that literary sociology sees literature as the social and cultural documents of a society. Moreover, Pradopo (1992) also views those sociological approaches, activities, and thinking in literature aim to obtain a complete and indepth picture of the author's relationship, the literary work he produces, and society as a source of literary creation.

Darma (2019) also shares the same view, stating that literature shows the inseparable relationship between the author with the political, social, economic, religious, cultural realities of society. As literature always talks about human destiny, beliefs and how a society runs a religious system. In addition, literature also discusses the question of nature, the man himself in society.

A similar thing is also stated by Sujarwa (2019) that social science and sociology of literature can complement each other. Both are equally intended to understand and describe human beings. Whether human beings as individuals or in social interactions are capable of producing a particular culture through aesthetic and imaginative symbols.

Referring to the above views, then, this article is in the mindset that agrees with the view that literature cannot be released from society (Kamarudin \& Rashid, 2021). Especially seeing that Usman Awang, the author of the Uda and Dara manuscript is attached closely to the social context of Malay society. Usman Awang, who was born long before Malaysia's independence (1929) has exposed him to the reality of the Malay community before and after becoming an independent nation. Left to die by his mother when he was young, it inevitably forced Usman Awang to grow up in poverty. As a result of poverty, he could not continue his education after only finishing Malay School (Jaafar, 2005).

Japan's expansion almost to the whole of Asia, including Malaysia in 1942 confronted Usman Awang on the fact that the Malays were still colonized. His childhood in poverty forced Usman Awang to live forcibly by the Japanese as a labourer in Singapore. Usman Awang was forced to enter as one of the Japanese forces before the Japanese was defeated and managed to escape from it when, the British finally returned to occupy Malaysia in 1946. However, Usman Awang suffered the same fate; namely by being forced to join the Police under British rules and regulations.

In some measure, the context of Usman Awang's life journey, cannot be released just like that in the process of authorship. The feeling of being a minor, a commoner living in defeat and inner suffering, has seeped into the space of Usman Awang's imagination, which, in turn, metamorphosed aesthetically into one of his great works, the Uda and Dara manuscripts. As stated by Faruk (2010) that the manuscript of Uda and Dara can be said to be Usman Awang's effort to recreate the social world of the Malay society in which there is their relationship in 
the family, social environment, politics, country, and economy. Generally, the issue is also an area of sociological discussion. On the other hand, Usman Awang can be said to be an intellectual who tries to see the reality of Malay society which is always in the shackles of the elite dominant (Harjito, 2014). This is because Allahyarham's creative works are not just a creative spark. Moreover, that frame of mind is not only able to intrigue people about the past and present but also the question of the future of the nation (Utusan Malaysia, 2008).

Although as a theatre script that was first staged in 1972, but if seen through Usman Awang's thoughts, Uda and Dara's script was not originally made as script. In fact, the idea came all the way back in 1954, which is from a poem written by Usman Awang entitled Gadis Kuburan. Subsequently, in 1956 the poem developed into a short story entitled Uda dan Dara (Awang, 1976).

Tracing the traces of these thoughts, it can be deduced that in terms of Usman Awang's great thinking and creativity, both the poem Gadis Kuburan and the short story Uda dan Dara including its music, have not undergone major changes. All these creative works have shown Usman Awang's critical thinking and resistance to the humanity facts of the Malay community. Differences in social status, backwardness in possessing critical thinking, colonialism, low self-esteem are the main problems that appear in the critical, intellectual and inner eyes of Usman Awang. The humanity facts of Malay society prompted Usman Awang to take a clear resistance stance.

Because the manuscripts of Uda and Dara were made in the concept of musical theatre, Usman Awang increasingly found space and time to develop critical reasoning on the Malay society reality which is contrary to the dreams and imagination of Usman Awang's views. For him, the Malay society should be able to achieve even higher honours. Hence, it is not appropriate to suffer a fate that is always in colonialism and stabbing each other. This is due to some point of view problems as stated by (Nurgiantoro, 2005) that is, Malay people have problems with themselves because the understanding of Malay values that belong, does not succeed in making those who belong to the social elite give adequate respect to lower social groups. Furthermore, Malay people had problems with each other in the social sphere, where the elite group created new colonies after independence from Western colonization. Lastly, Malay society has a vertical problem. In this case, it is seen that knowledge and belief in high Islamic and Malay values do not make them able to build a social system that is equivalent to one another.

\section{Objective}

(1) To analyse Usman Awang's resistance to the Malay humanity facts.

(2) To explore Malay elite colonialization practised to the fellow Malay's.

\section{Methodology}

Just as sociology focuses on the deepening of society, literature is also the result of the author's thinking that is based on human problems in society. In other words, Sociology and literature both focus their thinking on society. Therefore, although this article wants to look at Usman Awang's resistance, the opposition found a contradiction that has been poured into the narrative text (Endraswara, 2013). In the Uda and Dara manuscript, there is a connection linking it to the reality of Malay society (Al-Ma'ruf \& Nugrahani, 2017), providing real situation in both written and current context. Therefore, a narrative text analysis procedure that begins with an in-depth selection of the text contained in the manuscript is essential. As Stokes (2006) noted that deepening efforts as a whole are crucial as part of narrative text analysis. 
From the deepening process, the definition of Usman Awang's frame of mind was then created so that the flow of resistance that can be found in the Uda and Dara manuscripts became clearer.

To explore in more deepest part about Usman Awang's resistance in the Uda and Dara manuscripts, the sociology of literature approach is used by highlighting the qualitative descriptive reason for the opposition. As a first step, read repeatedly the manuscript of Uda and Dara to identify the data in detail that refer to the problems related to Usman Awang's resistance. And next, the data were classified according to the types and indicators of resistance contained in the Uda and Dara manuscripts. The third step is to perform the extended meaning by describing the data after going through the analysis process. The last one draws a conclusion based on findings preceded by careful testing so that Usman Awang's resistance can be understood in profundity.

The analysis and identification steps are carried out to first identify the form of Usman Awang's resistance in the Uda and Dara manuscripts. This step aims to look in detail at the system and ideology of the contradiction being conducted. The next step is to identify the social groups opposed by Usman Awang. This identification aims to analyse in-depth the social system that occurs in the society and how it is carried out in the context of the reality of the Malay society, which is marginalized by the elite social group of Malay society.

\section{Results and Discussion}

\section{Malay Islam as a Foundation for the Strengthening of Society Character}

Expressed as Malay Islam because what is referred to is the Malay society that has situated Islam, not only as the official religion of the country but the Malay society that has formed Islam as a philosophy, character building and the whole thinking of Malay society (Rahman, 1981). In the context of the Uda and Dara manuscripts, Usman Awang wants to place the basic concept of developing the Malay society as Islamic, which adopts a concept of equal social status. Malay brotherhood in Islamic values aims to develop unity, friendliness and the spirit of helping each other. In fact, Rajendran (1993) stated that the concept of caste is no longer relevant to be applied to Malay society after Islam became the official religion of the Malays. Usman Awang's assertion that shows that Islam as the basis for the strengthening of Malay character can be referred to the plot structure of the Uda and Dara manuscripts. A discussion of Islamic values is placed as a scene opener. Through the character of Pak Guru, Usman Awang highlights the thought as the following dialogue of the character of Guru:

\section{Kubelah teja kubelah jingga}

Mentera keramat kata terbilang

Bismillah kata langkah bermula

Bunga silat pembuka gelanggan (Awang, 1976).
I'm spiliting Teja and Jingga

Sacred incantation the word counts

In the name of Allah the word step begin

The flower of silat that opening arena (Awang, 1979)

The main Malay's view of life resource is Islam.

And the Bismillah describes the whole estuary of that view of life

In Usman Awang's concept, the selection of Bismillah is the main basis. Although placed in the third line, but Bismillah gave birth to a very strong character. The character taken from the value of Bismillah is what the Malay society should have. Strong also means that the mastery of silat is one of the main Malays as a nation characteristics. In another sense, Usman 
Awang wants to emphasize that Malay strength contains physical, spiritual, and mental elements. This can be seen from the dialogue of Guru's character above, where physical activity is not said to strengthen when there is no spiritual power. And, both of the elements are constructed by critical thinking skills.

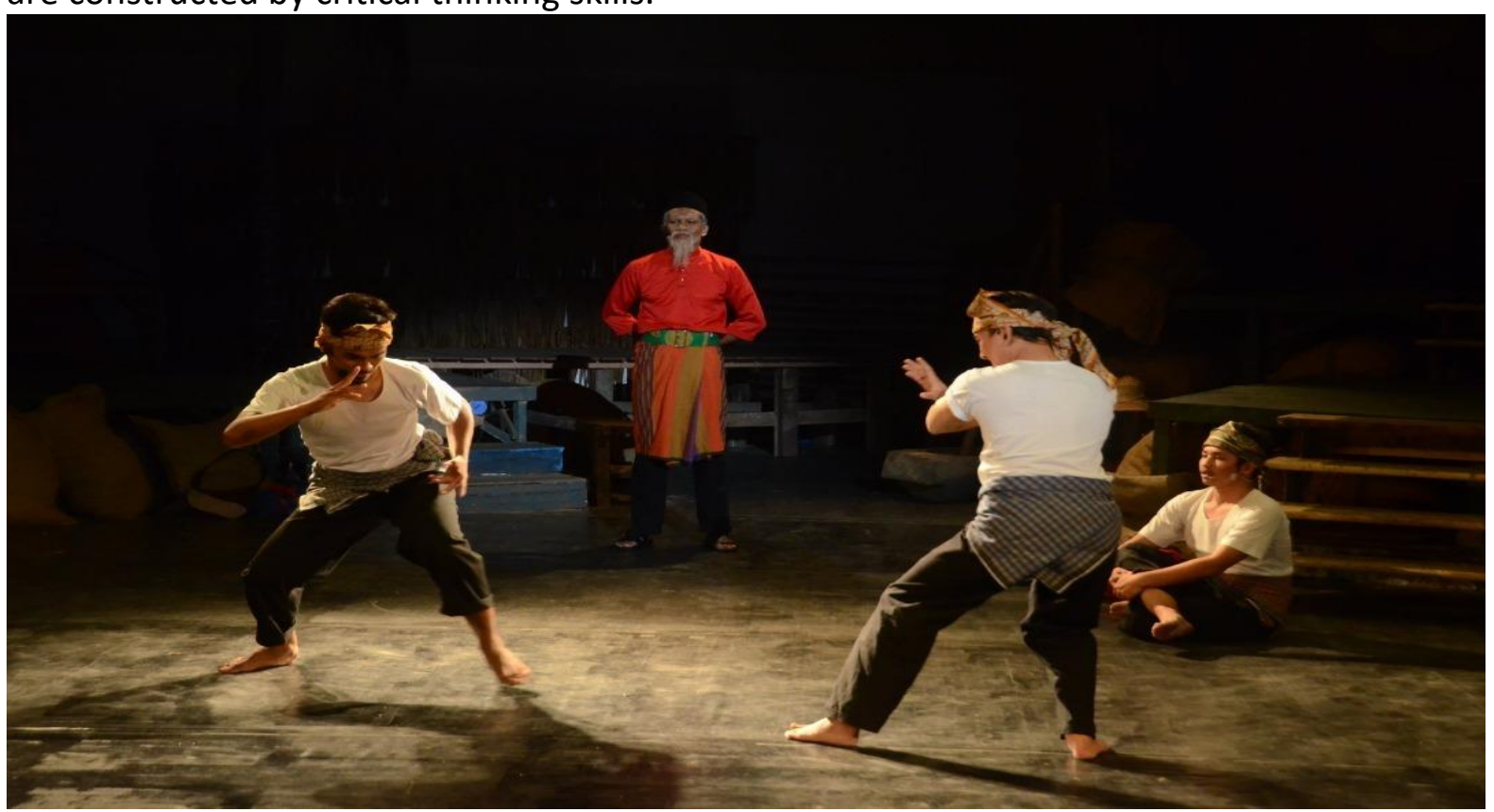

Figures 1 Silat as the opening scene in the Uda and Dara theatre performance (Source: The PROPERA documents. Was performed on 21st to 24th February 2019 at Panggung Budaya FMSP, UPSI. Directed by Nazrin Ahmad Nazri. And has been supervised by Lena Farida Chin)

The choice of Islamic values to open the whole story of Uda and Dara is not without reason. Because apart from containing Islamic values, silat also wants to be shown by Usman Awang as a great Malay civilization that takes Islamic as the main source of creation. Through silat scenes taught to the next generation of Malays, Usman Awang developed the concept that Malays cannot be separated from the history of their ancestors who have strong personalities, obedient and loyal to every principle taught and value inherited continuously. In other views, in the frame of mind of Usman Awang, Malay strength is placed on the loyalty of inheriting every Malay civilization that originates from Islamic values.

More details can be seen in the quote below:

Anak-anakku sekalian, Hari ini kemenyan diasapkan

Paku dan buah keras tamatnya pengajaran Ilmu nenek moyang pusaka yang ditinggalkan.

Silat mengajarkan ketabahan, cekal diri, sifat berani tahan uji. Silat menjadi Permainan pendekar di masa aman

Gerak menghadapi lawan membela keadilan

Langkah menyusung musuh bila berperang
Dear children,

Today incense is smoked

Nails and hard fruit are the ends of the lesson

The knowledge of the ancestral heritage left behind.

Silat teaches perseverance, self-restraint, courage to withstand the test. Silat became a swordsman's game in peace Motion to face the opponent defends justice Steps to carry the enemy when at war 
Tangkas dalam fikir mencari kebenaran Agile in thinking to find the truth (Awang, (Awang, 1976). 1976).

Silat is an expression of Malay culture that cannot be separated from Islamic values

Through the dialogue of Pak Guru's character above, Usman Awang formulated the basic character that must belong to Malays are those who are united with Islam, in addition to the loyalty of being Malay Muslim, Malay society must have perseverance, courage, strength to train and accept life tests to strengthen the soul. It can also be understood, Usman Awang did not forget the character's focus on critical thinking that aims to find the truth. Of course, one of what Usman Awang means is justice, both in the sense of social justice, such as economic and legal justice that is enforced in society. However, there is a criticism of Usman Awang that is quite prominent. On the one hand, courage is the main character in Malay society, while on the other hand, Usman Awang shows that Malay society prefers the nature of surrender as implied in the dialogue of Pak Guru's character:

Tapi ilmu silat tidak untuk dibanggakan Yang mustahak adalah kesabaran (Awang, 1976).
However, the silat is not to be proud of What is important is patience (Awang, 1976).

This is one of the basic concepts of how Malay in socio-religious practised

It seems that Usman Awang wants to emphasize that Malay society should strengthen the character of courage contained in the Malay Islamic values in order to be brave enough to show resistance against every colonialism. However, behind the courage of the struggle, Usman Awang created a synthesis that asserted that the Malay way of fighting should refer to the guidance of Malay and Islamic values. Through different observations, in all matters, Malay society must refer to the Malay Islam values correctly.

The resistance is aimed at re-establishing the dignity and prestige that has been usurped, not simply eradicating colonialism. To achieve all that, Usman Awang expressed the concept of the greatness of the ideal Malay society. Of course, the narrative does not immediately arise from an empty space. It is because Usman Awang appreciates the inner experience that is in contact with the reality of Malay society. The Malay people who lived in colonialism were able to survive and develop into an independent nation. Through the dialogue of Pak Guru's character, Usman Awang develops an ideal imagination about the facts of humanity that should happen to the Malay society to achieve a better equilibrium (Goldmann, 1981) as follows:

\section{Seorang pendekar tajam mata}

Tajam penciuman tajam pendengaran

Tiap detik di mana saja selalu sedia

Ibarat harimau walau dalam tidurnya

Berdetik sedikit bingkas ia

Tangkas bersedia;

Jika merendah menangkap puyuh berlari
A warrior has sharp-eyed

Sharp-olfactory sharp-hearing

Every second anywhere is always available

Like a tiger even in its sleep

Ticking a little resilient it

Agile ready;

If low catch a running quail 
Jika melompat menyambar burung terbang If jumping grabs a flying bird (Awang, 1976). (Awang, 1976).

The philosophy of silat and how to practice in social reality

Referring to the dialogue, it seems that Usman Awang is against the reality that shows the defeat of the Malay society because the fate of the abuse is not appropriate. Therefore, to achieve the dream of Malay society, Usman Awang gave a firm stance. Malay Islam as the umbrella of all social, economic, cultural, legitimacy and political life, which, by Goldmann (1981) referred to as the worldview or ideology of Usman Awang, who existed as a Malay. Ideas, inspirations and feelings are contained in the manuscript of Uda and Dara (in Faruk, 1994).

\section{Poverty is the Significant Malay Society Problem}

Why did Usman Awang make an effort to develop such a strong Malay concept based on Islamic? If we refer to the manuscripts of Uda and Dara, it can be understood that Usman Awang is trying to represent himself as the Malays who are always oppressed by poverty. In a different sense, Usman Awang realized the Malays as a great nation, living in a society in a fertile natural situation but always in poverty. In this case, Usman Awang's attitude is firm that poverty is the main problem for most Malays. There is a contradiction that Usman Awang highlights this issue because of the social and economic inequality experienced by Malay society. It can be seen in the part where the Malay society is portrayed as hard workers, diligent workers who spend almost all of their time in the fields. Usman Awang seems to understand correctly the philosophy of life of the Malay race which attaches all time and body with nature to develop a better life, such as the following songs and dialogues:

Balik, baliklah ke pondok kita

Badan letih, letih teruk bekerja

Balik, baliklah petani di sawah

Mencangkul menajak peluh mencurah.

Tiap subuh sudah ke ladang

Embun yang sejuk tak diendahkan (Awang, Cold dew is ignored (Awang, 1976).
Go back, go back to our hut Body tired, badly tired of working Go back, go back to the farmers in the fields Hoeing invites sweat pouring.

Every morning I went to the field 1976).

The basis of the Malays' outlook on life in internalizing reality

Meanwhile, in a different perspective, Usman Awang also shows the weak Malay society, which does not have the strength to fight the reality of colonialism. So, what happened then, Malay society could only sorrow their own fate in the psychological atmosphere. Swallowing his own bitter feelings and lacking the self-confidence to express those tormented feelings into a resistance expression. The ambivalence and contradiction of the social reality of Malay society is clearly the basis of Usman Awang's authorship uprising.

The Mother/Ibu character dialogue, for example, can be referenced as follows: 
Tiap pagi hanyalah merebus air

Minumlah kami air panas semata

Kalau pun kopi tak bergula

Suamiku bekerja saya pun bekerja.

Pondok buruk sawah sedepa

Petang pulang hampirlah senja

Sayur pucuk paku garam sebuku

Inilah makanan untuk anak-anakku (Awang, 1976).
Our breakfast is plain warm water

Or sometimes coffee without sugar

Then off we go into the fray

To toil the livelong day

From tiny hut to tiny rice-plot

From dawn to dust we'll be working there

Paku shoot and a bit of salt

Are our children's daily fare (Amin \& Ishak, 1995).

Internalizing oneself with reality is one of the most prominent Malay characters

The portrait of poverty is not unacceptable to Usman Awang because the situation of impoverishment is really like that. In Usman Awang's view, poverty is not destiny, but the design of high social groups. Conflict of interest of elite Malays. It is a form of their hegemony over other Malays who are in poverty (Harjito, 2014). The practice of the Malay elite hegemony can be seen by preventing and threatening to the lowest level. The threat posed by the elite group is a visualization of their ideology of power against weak Malays.

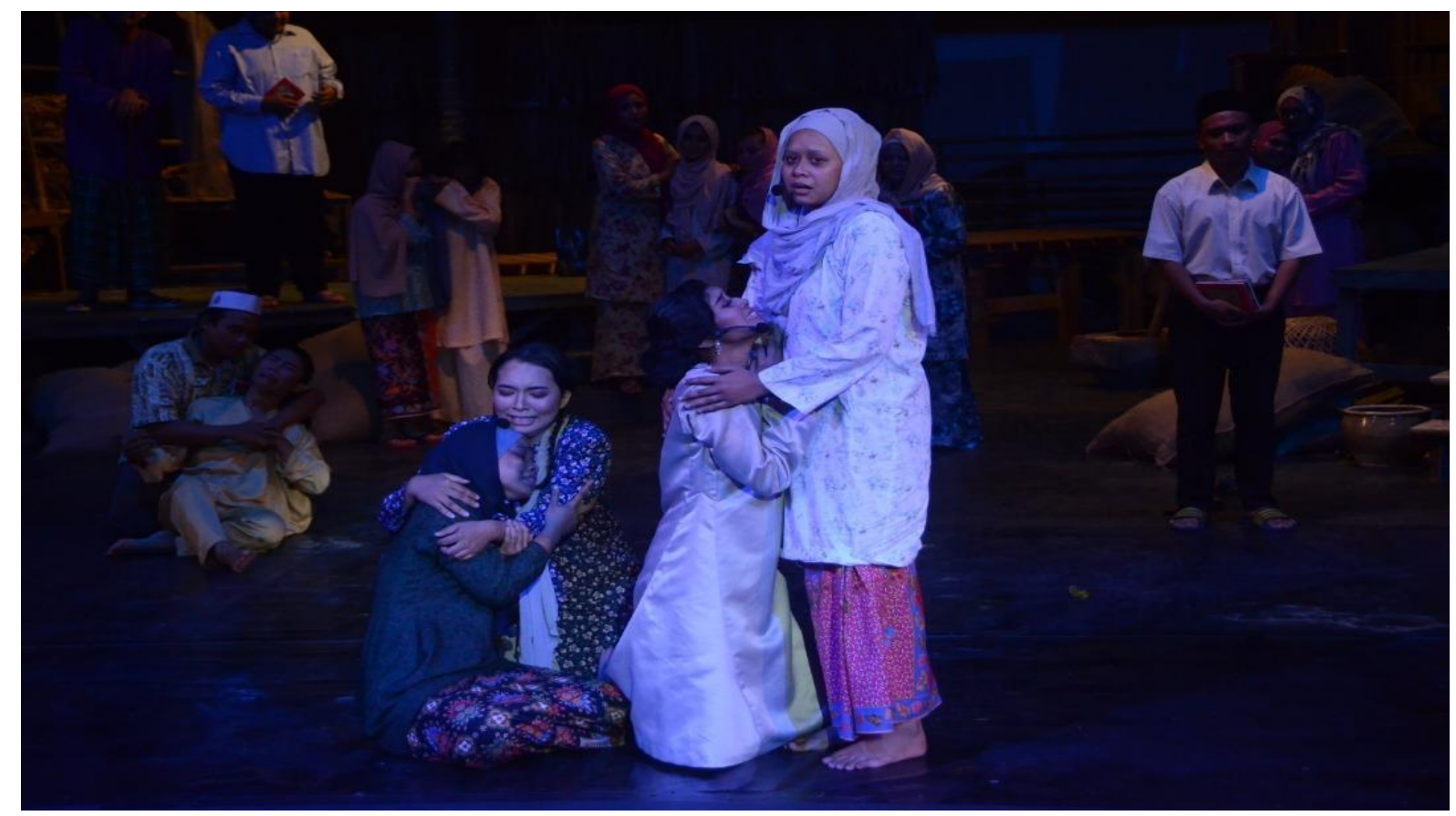

Figures 2 One of the scenes where the Marhaen afflicted a tragic defeat

(Source: The PROPERA documents. Was performed on 21st to 24th February 2019 at Panggung Budaya FMSP, UPSI. Directed by Nazrin Ahmad Nazri. And has been supervised by Lena Farida Chin)

The above dialogue does not show that Malay society with low social status does not have property. Although not comparable to the wealth possessed by some elites, for fear of a more powerful group, they kept the property as a hostage in times of need. This is so that they are not killed or tortured. This is a situation that does not make sense in Usman Awang perspectives. Thus, it develops the concept of an awareness of resistance to poverty 
deliberately created by the elite. In this case, it is clear that the text presented by Usman Awang is as a counter to the hegemony of the text of the Malay elite. Taking the position as the representative of marginalized Malays, Usman Awang increasingly reinforced that the reality of Malay poverty in general cannot be separated from Usman Awang's view of life and historical relationship with that reality (Harjito, 2014).

The above phenomenon triggered Usman Awang's opposition as quoted below:

Tak beras antah digesek

Tak kayu jenjang dikeping

Tak air hujan ditampang

Tak emas bongkah diasah (Awang, 1976).
If there's no rice we'll pound the husk If there's no wood we'll chop a ladder If there's no water we'll collect the rain If there's no gold we'll polish a nugget (Amin \& Ishak, 1995).

Struggling to survive is the Malay personality

The Malays society character who willingly accepted the situation of impoverishment, in Usman Awang's view has further strengthened the problem of poverty because apart from being a poor situation, the desire to accept poverty also seems to be given by God. Even though it was designed by crony Malays who have high powers. This shows that the poverty of the Malays is also due to mentality factors other than social reality which shows the same phenomenon.

\section{The Commendation of Social Structure as a Malay Mentality}

As a literary creative work, Uda and Dara cannot be separated from Usman Awang's (Heryanto, 1985) social-political alliance with some Malay elite groups who are described as the ruling group over their nation. The issue of social inequality contained in the Uda and Dara manuscripts is one of the most highlighted. However, that does not mean that social differences is the main idea of Usman Awang. Based on Usman Awang's view, differentiation in social status is only a corollary of the confusion of Malay society in understanding and carrying out the values of Malay Islam. The idolization of privilege and social structure is excessively higher, on the one hand, is the Malay mentality, and on the other hand, is the deliberate planting of elite groups so that their authority continues.

The feeble economic situation as well as being in Western colonialism for a long time, have been the undeniable reasons for successfully creating a different social status in Malay society. An important thing that appears in the Uda and Dara manuscripts is that Usman Awang does not clearly show the lineage and system of government that exists in Malay society. Unless Usman Awang strengthens the economic cause and the weakness of knowledge as the main factor driving the emergence of social status inequality. It case can be seen in the character of Alang Bakhil, which is not stated as a character from the descendants of the Malay aristocracy. Usman Awang created the character from the general public but has a very strong power in the economic field. 


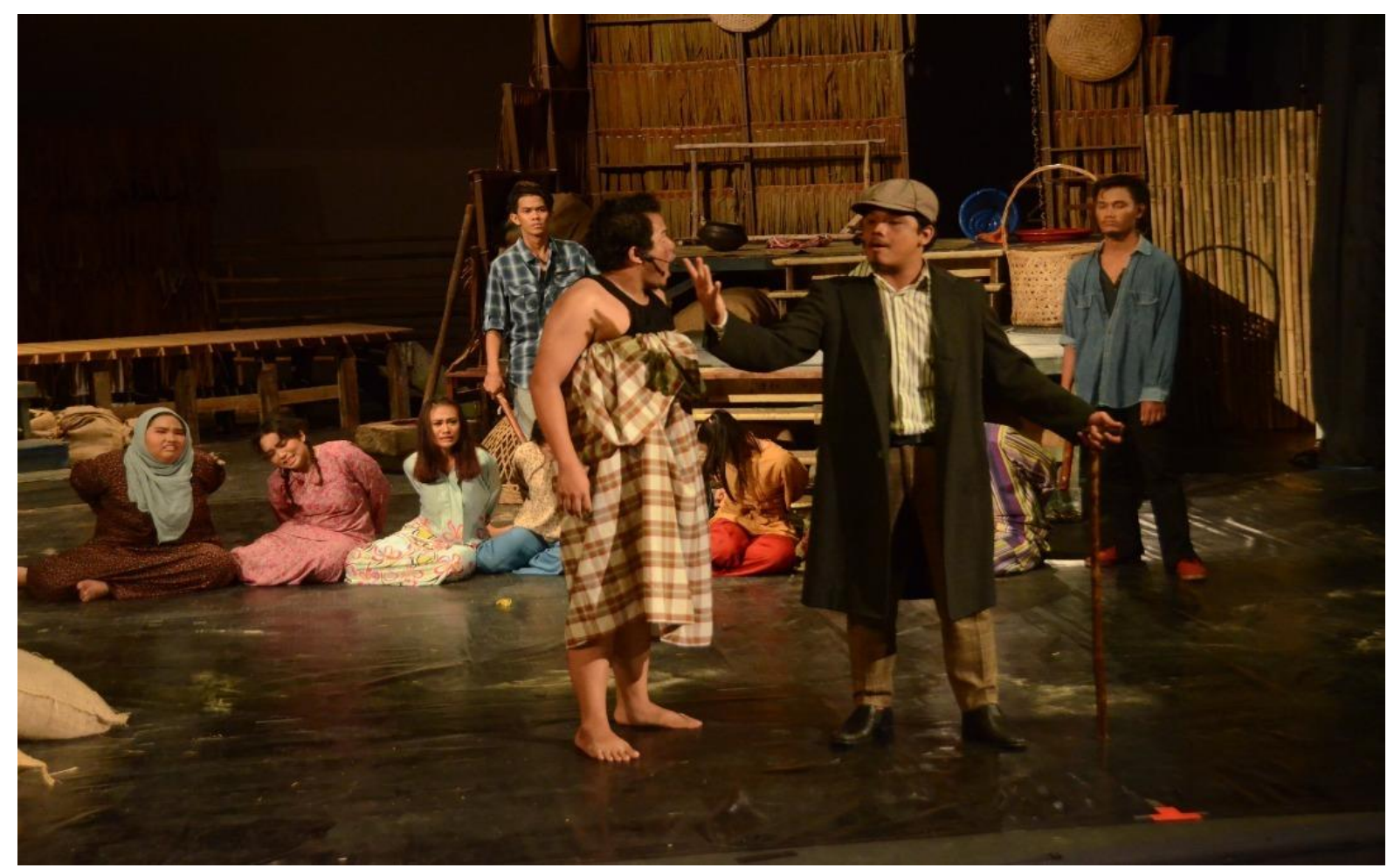

Figures 3 One scene in which the traits of superior social groups dominate the others in the Uda and Dara theatre performance

(Source: The PROPERA documents. Was performed on 21st to 24th February 2019 at Panggung Budaya FMSP, UPSI. Directed by Nazrin Ahmad Nazri. And has been supervised by Lena Farida Chin)

In the manuscript of Uda and Dara, Usman gives an assertion about the character traits of superior social groups. The assertion is meant to make it clear that such high social groups are ubiquitous. But it does not characterize the origin of the aristocracy. Although Usman Awang criticized this group of people of elite social status as a whole, the criticism presented in general further strengthens the understanding that the tall social status is meant more to the Malay society in general. This means that Malay mentality that is very passionate about being idolized can happen to anyone. 
Alang Bakhil's dialogue underneath shows the above:

$\begin{array}{ll}\text { Aku kaya ada ladang ada sawah } & \text { I'm rich } \\ \text { Aku kaya ada emas ada ringgit } & \text { I've gote estate and rice fields } \\ \text { Aku kaya ada rupa ada gaya } & \text { I'm rich } \\ \begin{array}{l}\text { Aku kaya aku punya semua harta } \\ \text { Aku kaya tanah pajak tanah lelong }\end{array} & \text { I've got gold and ringgit } \\ \begin{array}{l}\text { Aku kaya apa kata ikut saja. } \\ \text { Aku kaya beri hutang beri pinjam }\end{array} & \text { I'm rich } \\ \text { Aku kaya boleh buat apa suka } & \text { I've got looks and style } \\ \text { Aku kaya aku raja orang desa (Awang, } & \text { I'm rich } \\ \text { 1976). I'm rich } & \text { I've seize mortgaged land } \\ & \text { I'm rich and my word is law (Amin \& Ishak, } \\ & \text { 1995). }\end{array}$

Some characters that symbolize the Malays elite

Characterization as a person who likes to show off properties shows excessive strength, sharing loans seems like kindness, but it is a mode of colonization to fellow Malays. That also include declaring himself arrogantly as a king in a place that is felt like power territories are deliberately highlighted by Usman Awang to further clarify the scope of the resistance that is Malay society in general. These characteristics seem more identical when viewed from the point of view of the Malay social and cultural system. Not from the existing system of government. In other words, Usman Awang would like to state that the practice of arrogance of elite social groups occurs every day, whether in cities or distant villages.

Furthermore, it can also be seen from Alang Bakhil's character dialogues below:

Rampas padinya, rampas padi ganti rugi Rampas padinya, rampas padi tolak hutang Rampas padinya, rampas semua bidang tanah Rampas padinya, rampas ambil semua sawah (Awang, 1976).
Seize the rice for, seize the rice for compensation

Seize the rice for, seize the rice to pay their debts

Seize the rice for, seize all their lands

Seize the rice for, seize all their rice fields (Amin \& Ishak, 1995).

Several other characters who also symbolize the Malays elite

Such Malays elite spread everywhere and created a system for continuous colonization. This situation, shown by Usman Awang because social elites have succeeded in creating a system of power that is different from the official system of government. For example, they can punish low social society arbitrarily without reference to the country's official laws. Its similar situation happened in tax collection. Their manner more closely resembled the forcible confiscation of Marhaen properties. The economic system is controlled by creating savings and loans. In this case, the application of high-interest loans is applied. This aims to further ensnare society so that the Marhaen group becomes weaker. Hence, the main purpose of all such practised methods is unbounded power.

For Usman Awang, it may be that the aristocracy does not endanger or threaten Malay society in the future because it was raised by consensus from hundreds of years ago. Aristocracy did 
not appear to have a significant conflict of values with the Muslim Malays. Yet in contrast to the social elite, which has essentially gone far off. They created their laws and declared themselves as absolute ruler over societies. Unfortunately, there are no controls that can be enforced to reduce crime practised. That is why, for Usman Awang, who one village authorities are a threat to the Malay society.

The power of the social elite occurs continuously. Practised almost throughout society's life. Although they are not appointed as rulers, yet because the laws were created by themselves, then automatically the Marhaen society is bound and unable to form itself. As shown in the Uda dan Dara script, in this context, Usman Awang emphasized endless strong resistance.

\section{Malays' Mistakes in Understanding Riches Property}

Basically, through the Uda character, Usman Awang wants to convey criticism on many things. One of them is the offence of interpreting wealth that is centred on the ownership of property alone. Feeling weakened by social elites because of poverty. Uda's character concludes that only property can be a resistance appliance. Eventually, the action he took was to go to town to collect property.

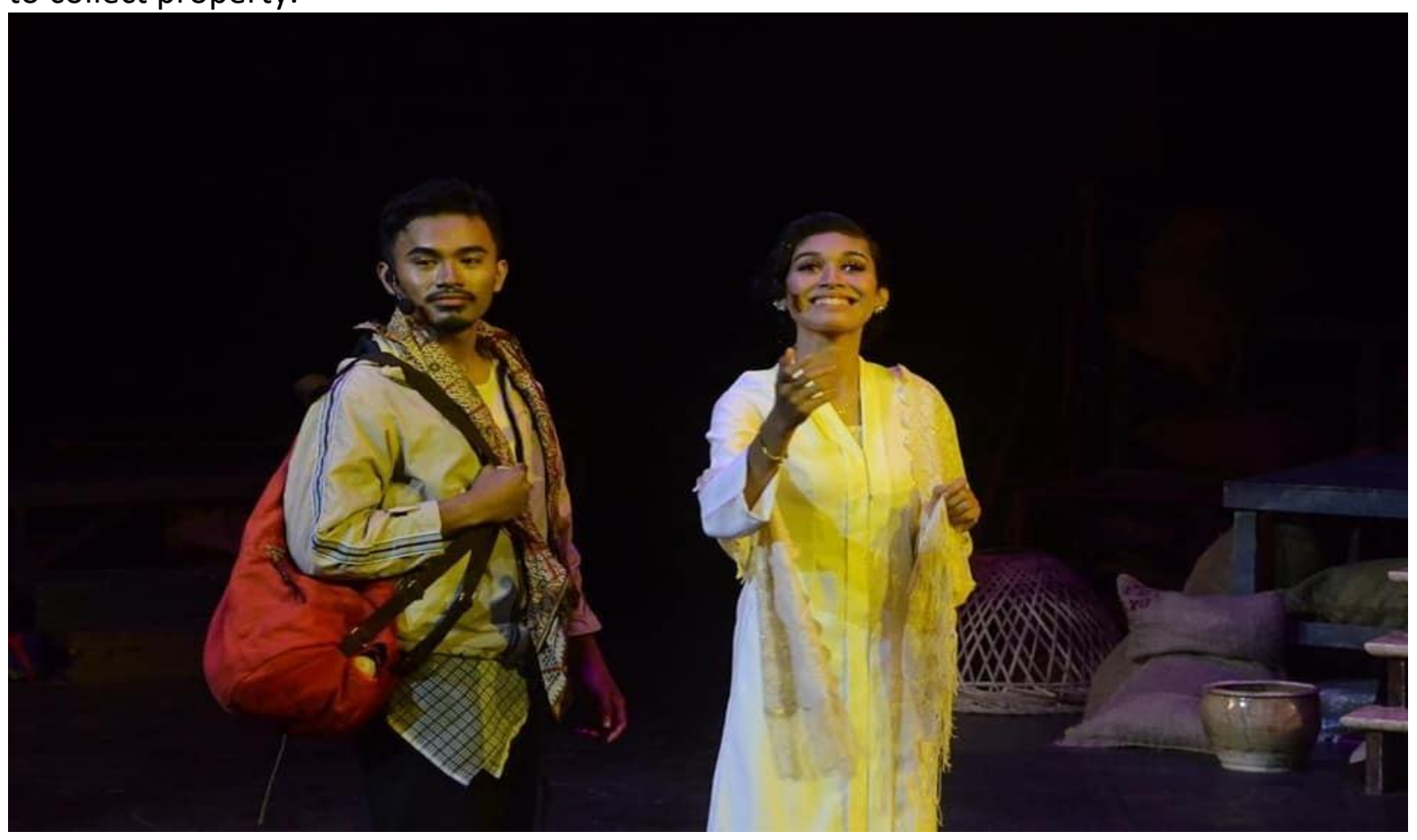

Figures 4 The scene where the Uda Character will go to the city

(Source: The PROPERA documents. Was performed on 21st to 24th February 2019 at Panggung Budaya FMSP, UPSI. Directed by Nazrin Ahmad Nazri. And has been supervised by Lena Farida Chin)

Uda's character has forgotten that as long as he is staying in the city, the social elite is increasingly blackmailing and seizing property from the Marhaen and further strengthening their power by torturing, including torturing Uda's mother. Other views, the riches properties acquired by Uda's character, did not succeed in exceeding elite riches because the opportunities and power had become stronger. In fact, as long as Uda's character is not living in his village, ideologically, and fighting spirit to build resistance further have been weakened by the painful situation. In this context, Uda's character has been taken a wrong way. In one dialogue he states something like this: 
Emas sudah hamba carikan

Ringgit sudah hamba longgokkan

Bergadai tulang empat kerat

Mencerut perut melipat belikat

Siang bekerja, malam bekerja

Bekerja di mana saja

Dara tak hamba lepaskan begitu saja!

Dengarlah sumpah-jantan sumpah-

pendekar

Lama hamba berlembut hamba bersabar

Sekali ini desa ini hamba bakar

Hamba bakar hamba amuk musnahkan (Awang, 1976).
I've got the gold

I've piled up the ringgit

I've slogged and sweated

I've starved and fretted

Night and day high and low

I've strudged to and fro

I'll never let Dara go!

Listen to a man's vow, a warrior's vow

I've ling been patient, but now

$I^{\prime} l l$ set this village aflame

I'll burn and kill and main

I'll destroy everything in the amok game (Amin \& Ishak, 1995).

The fallacy of Malays' view to the belongings

It is very clear that, although Uda's character manages to amass possessions, yet in the end, he is unable to marry Dara's character. Uda's character dies before his goal is achieved. In this context, Usman Awang does not dismiss property as something important, especially since his background is lower social class. But richest properties are not the main thing. Usman Awang would like to emphasize that awareness as a ruling nation is a priority. From a different point of view, a collective subject is more valuable than individuality. Because of it, Malay can build a social resistance of collective nature. It means rather a strong social unity of society (Goldmann, 1981). More importantly, Usman Awang's focus is the authority on knowledge because, with knowledge, the Malay society can think critically about the problems themselves (Taum, 2018). In this case, Usman Awang symbolically conveyed the strong message through Utih's character.

\section{Aku bernama Utih}

Ditertawakan kerana sepatah kata 'gila'

Dari mereka yang sebenarnya gila:

Gila kerana harta-benda, gila kerana ringgit;

Gila kepada pangkat darjat kebesaran

Aku tau harta dan ringgit, cukup tahu

Bukan untuk gunanya, tapi kejahatan olehnya Kerana itulah aku tidak menyembahnya,

Tidak menjadi hambanya

Kerana seorang hamba dari harta dan ringgit Hamba kepada pangkat darjat dan kebesaran Terjadilah kejahatan kekejaman

Seperti yang aku saksikan kini

Aku kasihan dan sedih melihat kau menjadi Haiwan yang pandai berkata-kata! (Awang, 1976).
My name is Utih

Laughed at for saying 'crazy'

Of those who are actually crazy:

Crazy for possessions, crazy for dollars;

Crazy to the social level of greatness

I know wealth and money, I know enough

Not for how to use, but a crime by him

That's why I don't worship him,

Not to be his slave

Because a slave of wealth and money

Servants to luxuriant and greatness

There was a crime of cruelty

As I watch now

I'm sorry and sad to see you become

A talkative animal! (Awang, 1976). 
Strong autocriticism to the misconception Malays on property ownership

Furthermore, the taste, spirit, and purpose of Malay society togetherness is a very important basis to be able to formulate resistance strategies. After that, an act of courage should come from a strong understanding of Malay Islamic values. It means that the spirit of change and social struggle must come from Malay Islamic values. Hence, the reason behind why Usman Awang has started Uda and Dara by presenting Silat and Pak Guru's as central characters in this scene (Sutejo \& Kasnadi, 2016). In other views, the riches meant by Usman Awang is the awareness of being a Malay race that cannot colonize others and be colonized by anyone. To bring greater attention to this matter, Usman Awang declared a clear formulation of Malay Islamic values as the main and greatest Malay society way of life. This formulation is related to what Plato stated (in Damono, 1979) that Usman Awang is describing what is happening in Malay society as a humanity fact that reflects the Malay's in each era (Goldmann, 1967).

\title{
About the Critical Malays Imagination
}

Usman Awang's imagination of Malay's greatness, for example, can be seen in the following dialogue:

\author{
We must topple oppresssors \\ Else we'll lose our village in mortage \\ Else our land will all be gone \\ We must fight with unflinching courage \\ Prepared to die where we were born \\ We must fight; this land belongs ti the farmers \\ We must fight; this is land is ours (Amin \& Ishak, 1995).
}

The important position of the dialogue is that it was launched after Marhaen began to realize the deep social inequalities they were experiencing. Ironically, inequality is not due to real colonizers, but by the Malays who social elite structure. Colonization from fellows Malays. In this case, Usman Awang would like to emphasize that such a social situation should not be allowed to occur in any situations. 


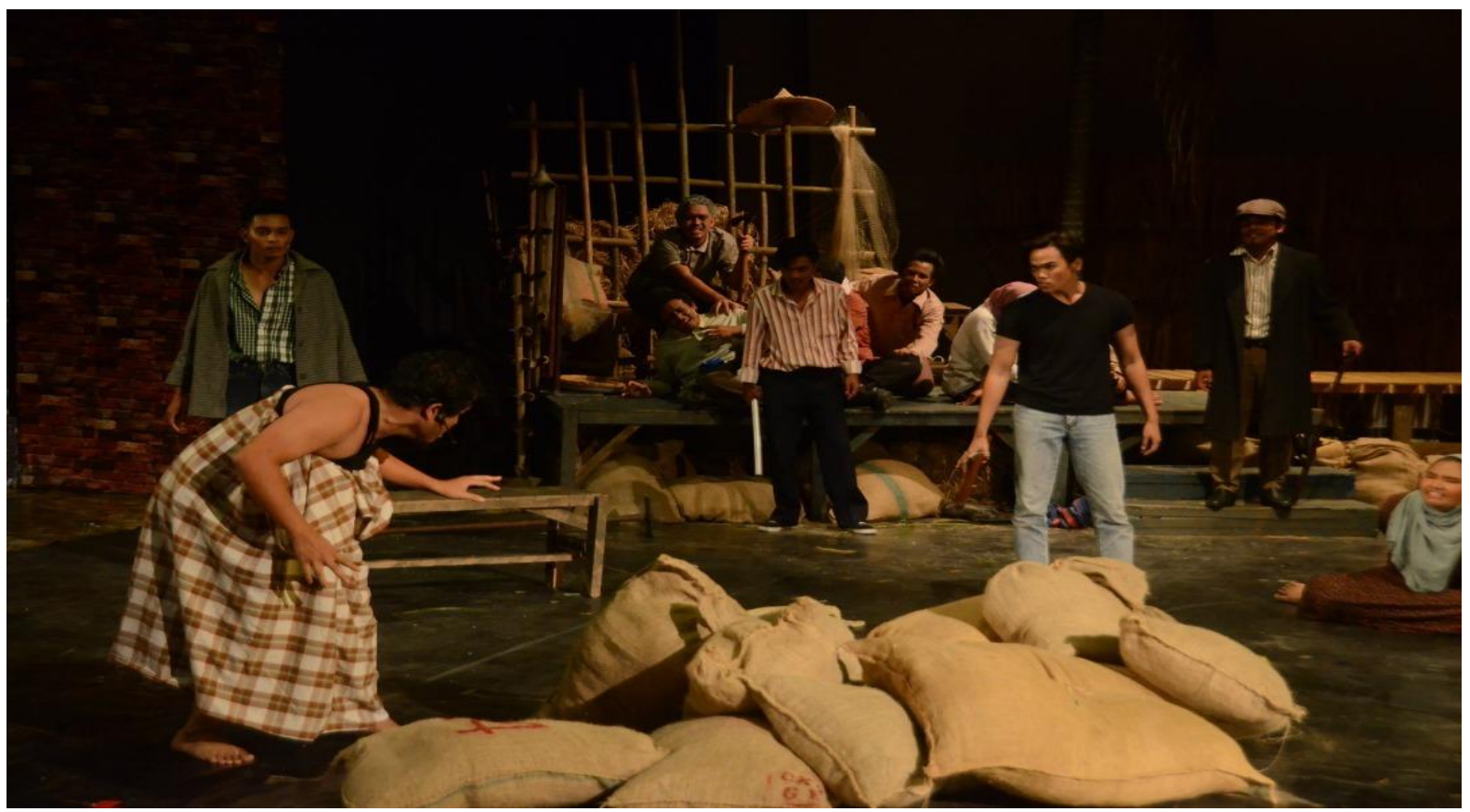

Figures 5 Utih's character in one of the resistance scenes to the social elite (Source: The PROPERA documents. Was performed on 21st to 24th February 2019 at Panggung Budaya FMSP, UPSI. Directed by Nazrin Ahmad Nazri. And has been supervised by Lena Farida Chin)

To strengthen resistance ideas and actions, Usman Awang cleverly created Utih's character. Through Utih's character, Usman Awang staged a fight against the Malay society which is shackled by power. Therefore, freedom of thought, freedom of speech and opinion, freedom of action are great critical constructions of Usman Awang through the Utih's character. This construction aims to build the Malays awareness. Usman Awang realized, in fact, that there are some Malays who have begun to dare to think critically. From this social small part, Usman Awang wanted the resistance to superiority social elites to be started.

Utih's character is deliberately placed in the surrealism space and time, which is also realism at the same time. Like a part Utih's character dialogue below:

Ha, sudah kuteka telah kusangka

Bila aku tiada, tiada di mana-mana

Orang akan bertanya, dan bertanya

Ke mana, dan di mana dia?

O, Utih, di manakah kau Utih? (Awang, 1976).
$\mathrm{Ha}$, I was a guess and suspected

When I'm not there, I'm not anywhere

People will ask, and ask more

Where is he gone, and where is he stay up?

Oh, Utih, where are you Utih? (Awang, 1976).

Symbolizes the subconscious of Malays character

Sometimes Utih has spoken based on a metaphysical point of view to symbolize the Malay society that hides in fear of voicing the truth. Sometimes also visualized by Usman Awang as an ordinary human being to reveal Malay society in a small group who have begun to be enlightened. Utih is a representation of Malay's subconscious that appears from their inner turmoil that resembles instinctual drives (Winner, 1982) which are basically able to push them to do a resistance so that the drive is not only in the subconscious (Freud, 1947). Thus, Utih is 
a depiction of a difficult situation which, by Usman Awang was created to be a symbol of resistance.

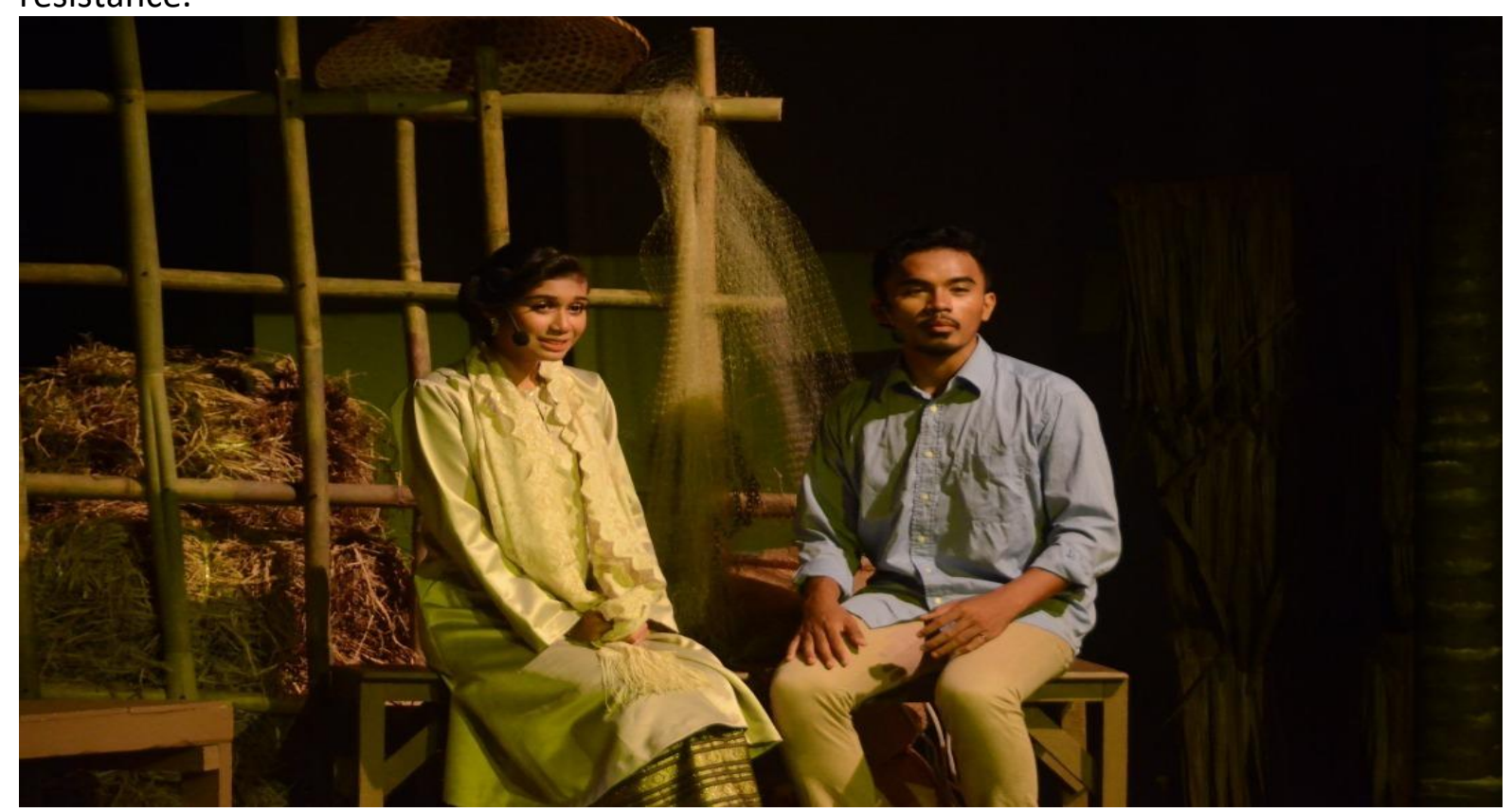

Figures 6 A romantic scene between the characters Uda and Dara

(Source: The PROPERA documents. Was performed on 21st to 24th February 2019 at Panggung Budaya FMSP, UPSI. Directed by Nazrin Ahmad Nazri. And has been supervised by Lena Farida Chin)

Thereafter, Usman Awang cleverly used the romantic concept (Djahwasi \& Saidon, 2021) to uncover the minds of the Malay society about the greatness of being in freedom. The ideals of independence cultivate riches and self-respect. As if referring to folklore, legends and the great Malay in the past, Usman Awang created an enchanting romantic journey between Uda's and Dara characters. Through both characters, Usman Awang wants to develop the Malay darkness era in perception, one side, in that darkness, the Malays dare to develop dreams and struggle to make it come true. Although Uda's character eventually died, at least he has fulfilled his true promise as a Malay, which is to fight to achieve his dream. Although in the end, Uda's character is more focused on the dignity of property, Usman Awang did not expand the question in this context by prioritizing the courage of Uda's character to pursue and get his dream. Thus, this is one of the logical reasons, why finally the character Uda is designed to die in the theatrical script of Uda and Dara. The decision made by the author, Usman Awang for the death of a character was simply to shine some enlightenment that focuses on the courage to take decisions to change the social, political and economic situation of society. Not focused on the idea of materialism that is slightly attached to Uda's character.

\section{Conclusion}

Referring to the description above, it can be found that the humanity Malay society fact has triggered Usman Awang's resistance. However, despite that, Usman Awang is aware of the real social reality. Through the section that tells the story of Uda character being murdered, Usman Awang motivated and inspired Malay society about the importance of resistance. Changes should be one of Usman Awang's purposes when writing the script. The death of Uda's character, in Usman Awang's concept, is a clear criticism of those who waited until the 
victim fell, just to give awareness towards the idea of resistance. Whereas, in fact, the colonialization situation has been going on for generations.

Through the concept of tragedy, Usman Awang raises awareness to Malay society about colonialism. After Uda character's death, Usman Awang immediately highlighted another special character. He is Malim. Through Malim's character, Usman Awang has constructed a great imagination which shares a critical Malay issue. On one hand, Usman Awang taught the lesson that colonialism is not easy to eradicate, while on the other hand, Usman Awang ignited a strong spirit and encouraged critical thinking. Usman Awan wants to argue that Malay society cannot remain silent. Despite the brunt of defeat, resistance to social elite arbitrariness should continue to be waged. In this situation, it can be seen that Usman Awang as a critical representation of Malay is the ideal situation dreamt of.

The inferior mentality of Malay's is the mainstream of Usman Awang's resistance. The subjectivity of Usman Awang as an author appears to give an assertion that the success he has achieved as a Malaysian National Laureate (Sastrawan Negara) is because his soul vitality is constantly turbulent to fight the reality of poverty and hardship that plagues his life. In Usman Awang's belief, the Malay society is definitely like that. Uda's character is a body which symbolizes that it can be defeated by anyone in this world, whereas Malim's character is a thought as well as a soul that should continue to burn Malay's self-esteem.

Therefore, as a whole, it can be understood that Usman Awang's resistance is based on an unbalanced Malay's social reality, which is because it does not carry out the values of Malay Islam in-depth and comprehensively.

\section{Acknowledgements}

This article was presented at the 2nd International Conference Malay Historiographical Literature (HISTIC-II, 2019). Hosted by Budiman Writers Association of Malaysia (BUDIMAN), Dewan Bahasa dan Pustaka. With the collaboration of Institut Peradaban Melayu Universiti Pendidikan Sultan Idris, Malaysia.

\section{Corresponding Author}

Nuriadi

English Education Program, Faculty of Teacher Training and Education University of Mataram, Indonesia

Email: nuriadi@unram.ac.id

\section{References}

Al-Ma'ruf, A. I. \& Nugrahani, F. (2017). Pengkajian Sastra Teori dan Aplikasi. Surakarta: C.V. Djiwa Amarta Press.

Amin, S., \& Ishak, S. (1995). Selected Play by Usman Awang (translated). Kuala Lumpur: Dewan Bahasa dan Pustaka.

Awang, U. (1976). Muzika Uda dan Dara. Kuala Lumpur: Dewan Bahasa dan PustakaKementerian Pelajaran Malaysia.

Damono, S. D. (1979). Sosiologi Sastra sebuah Pengantar Ringkas. Jakarta: Pusat Pembinaan dan Pengembangan Bahasa.

Darma, B. (2019). Pengantar Teori Sastra. Jakarta: Penerbit Buku Kompas.

Djahwasi, H. R., \& Saidon, Z. L. (2021). An Analysis of Artistic Form and Musical Perspective of Romantic Era Music. International Journal of Academic Research in Business and Social Sciences, 11(11), 771-782. 
Endraswara, S. (2013). Metodologi Penelitian Antropologi Sastra. Yogyakarta: Penerbit Ombak.

Faruk. (1994). Pengantar Sosiologi Sastra. Yogyakarta: Pustaka Pelajar.

Faruk. (2010). Pengantar Sosiologi Sastra dari Strukturalisme Genetik sampai PostModernisme. Yogyakarta: Pustaka Pelajar.

Freud, S. (1947). Leonardo da Vinci: a Study in Psychosexuality. New York: Random House.

Goldmann, L. (1967). "The Sociology of Literature: Status and Problems of Method" in International Social Science Journal, published quarterly by UNESCO, Vol. XIX No. 4, 1967.

Goldmann, L. (1981). Method in Sociology of Literature. Oxford: Basil Balckwill Publisher.

Harjito. (2014). Hegemoni Gramsci dalam Sastra Indonesia: Student Hijo, Nasionalisme, dan Wacana. Semarang: UPGRIS Press.

Heryanto, A. (1985). Perdebatan Sastra Kontekstual. Jakarta: C.V. Rajawali Press.

Jaafar, S. (2005). Wajah: Biografi Penulis. Kuala Lumpur. Dewan Bahasa dan Pustaka.

Kamarudin, N. B., \& Rashid, A. A. S. B. A. (2021). Feature Film Script Writing Quality Issues: KL Vampires Film (2019). International Journal of Academic Research in Business and Social Sciences, 11(11), 362-371.

Nurgiantoro, B. (2005). Teori Pengkajian Fiksi. Yogyakarta: Gadjah Mada University Press.

Pradopo, R. D. (2002). Kritik Sastra Indonesia Modern. Yogyakarta: Gama Media.

Rahman, A. H. A. (1981). Sejarah dan Pemikiran Islam. Selangor: Penerbitan Pena Sdn. Bhd.

Rajendran, M. (1993). Sejarah Islam. Petaling Jaya: IBS Buku.

Ratna, N. K. (2003). Paradigma Sosiologi Sastra. Yogyakarta: Pustaka Pelajar.

Ratna, N. K. (2007). Estetika Sastra dan Budaya. Yogyakarta: Pustaka Pelajar.

Stokes, J. (2006). How to Do Media and Cultural Studies. (translated Santi Indra Astuti). Yogyakarta: Bentang.

Suharianto, S. (1982). Dasar-dasar Teori Sastra. Surakarta: Widya Putra.

Sujarwa. (2019). Model dan Paradigma Teori Sastra. Yogyakarta: Fakultas Sastera, Budaya, dan Komunikasi Universitas Ahmad Dahlan.

Sutejo \& Kasnadi, H. (2016). Sosiologi Sastra Menguak Dimensionalitas Sosial dalam Sastra. Yogyakarta: Terakata.

Taum, Y. Y. (2018). Kajian Semiotika Godlob Danarto dalam Perspektif Teeuw. Yogyakarta: SDU Press.

Teew, A. (1988). Sastra dan Ilmu Sastra Pengantar Teori Sastra (cet. kedua). Jakarta: Pustaka Jaya-Girimukti Pasaka.

Winner, E. (1982). Invented World: the Psychology of the Arts. Cambridge: Harvard University Press.

\section{Newspaper}

Mengenali Usman Awang. (2008). Utusan Malaysia. P. 28. 